\title{
Carbon dynamics in the western Arctic Ocean: insights from full-depth carbon isotope profiles of DIC, DOC, and POC
}

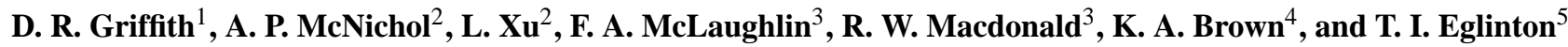 \\ ${ }^{1}$ MIT/WHOI Joint Program in Oceanography, 266 Woods Hole Rd., Woods Hole, MA 02543, USA \\ ${ }^{2}$ Dept. of Geology and Geophysics, Woods Hole Oceanographic Institution, 266 Woods Hole Rd., Woods Hole, \\ MA 02543, USA \\ ${ }^{3}$ Institute of Ocean Sciences, Fisheries and Oceans Canada, 9860 West Saanich Rd., Sidney, BC, V8L 4B2, Canada \\ ${ }^{4}$ Dept. of Earth and Ocean Sciences, University of British Columbia, 2146 Health Sciences Mall, Vancouver, BC, \\ V6T 1Z3, Canada \\ ${ }^{5}$ Geological Institute, Swiss Federal Institute of Technology, Sonneggstrasse 5, 8092 Zürich, Switzerland
}

Correspondence to: D. R. Griffith (dgriffith@whoi.edu)

Received: 17 October 2011 - Published in Biogeosciences Discuss.: 31 October 2011

Revised: 12 March 2012 - Accepted: 19 March 2012 - Published: 28 March 2012

\begin{abstract}
Arctic warming is projected to continue throughout the coming century. Yet, our currently limited understanding of the Arctic Ocean carbon cycle hinders our ability to predict how changing conditions will affect local Arctic ecosystems, regional carbon budgets, and global climate. We present here the first set of concurrent, full-depth, dualisotope profiles for dissolved inorganic carbon (DIC), dissolved organic carbon (DOC), and suspended particulate organic carbon (POCsusp) at two sites in the Canada Basin of the Arctic Ocean. The carbon isotope composition of sinking and suspended POC in the Arctic contrasts strongly with open ocean Atlantic and Pacific sites, pointing to a combination of inputs to Arctic POCsusp at depth, including surfacederived organic carbon (OC), sorbed/advected OC, and OC derived from in situ DIC fixation. The latter process appears to be particularly important at intermediate depths, where mass balance calculations suggest that $\mathrm{OC}$ derived from in situ DIC fixation contributes up to $22 \%$ of POCsusp. As in other oceans, surface-derived OC is still a dominant source to Arctic POCsusp. Yet, we suggest that significantly smaller vertical POC fluxes in the Canada Basin make it possible to see evidence of DIC fixation in the POCsusp pool even at the bulk isotope level.
\end{abstract}

\section{Introduction}

In the coming decades, the Arctic Ocean is predicted to experience significant changes in sea-ice conditions and in its coupling with terrestrial systems. If trends continue, the Arctic Ocean carbon cycle may change profoundly as summer sea-ice gives way to open water, permafrost thaws, coastal erosion and river inflow increase, and organisms and ecosystems adapt to these changes (Serreze et al., 2000). Yet our ability to accurately predict how Arctic Ocean ecosystems will respond is limited by an incomplete understanding of the Arctic carbon cycle and the dominant feedback mechanisms involved (McGuire et al., 2009).

Dual carbon isotope $\left({ }^{13} \mathrm{C}\right.$ and $\left.{ }^{14} \mathrm{C}\right)$ measurements represent a valuable tool to improve our understanding of presentday ocean biogeochemistry (e.g. McNichol and Aluwihare, 2007). Yet relatively few full-ocean-depth dissolved and particulate OC isotope profiles exist for the major ocean basins, and none have been reported in the Arctic, a unique system poised for change.

\section{Background}

The Arctic Ocean basin is filled by water from the Atlantic and Pacific oceans as well as Arctic rivers. Sea-ice limits wind-driven vertical mixing throughout much of the year which, together with strong stratification supported by inflowing waters, results in an ocean that is organized into several vertical layers (Stein and Macdonald, 2004). Surface waters $(0-30 \mathrm{~m})$ are strongly influenced by freshwater 
from rivers and melting sea-ice. Nutrient-replete Pacific waters dominate at depths between $30-250 \mathrm{~m}$ in the Canada Basin (e.g. Yamamoto-Kawai et al., 2008), while warm and salty Atlantic waters occupy intermediate depths (250 $1500 \mathrm{~m}$ ) and lie above the isolated deep water. Each layer has unique physicochemical characteristics that reflect source water composition and modifications by biogeochemical processes within the Arctic. A particularly important feature of the Arctic Ocean is the strong perennial cold halocline, which insulates surface waters (and sea-ice) from warm and salty Atlantic waters below (Shimada et al., 2005).

The Arctic Ocean receives a disproportionate share of the OC delivered from rivers to oceans worldwide (Stein and Macdonald, 2004). The Canada Basin (Fig. 1a) receives OC inputs from both North American (Mackenzie and Yukon) and Siberian rivers (Guay et al., 2009; YamamotoKawai et al., 2009). Particulate organic carbon (POC) from the Mackenzie River may reach the interior Canada Basin directly as fine particles or following deposition, resuspension, and lateral transport in nepheloid layers (Forest et al., 2007). Marine production by pelagic and sea-ice algae is also an important source of OC to the sediments and water column of the Canada Basin (Belicka et al., 2002).

In the Arctic, $\mathrm{POC}$ source assignments based on ${ }^{13} \mathrm{C}$ are difficult because of the diversity of possible sources, the relatively narrow range in environmental $\delta^{13} \mathrm{C}$ values, and large uncertainties in source signatures due to factors such as variable riverine OC flux (Raymond et al., 2007), in situ temperature, nutrient limitation, and phytoplankton growth rate (Goericke and Fry, 1994; Kennedy et al., 2002). Riverine POC inputs to this region have $\delta^{13} \mathrm{C}$ values of $\sim-26 \%$ o to $-29 \%$ o (Naidu et al., 2000), sea ice POC has values of $-15 \%$ o to $-22 \%$ (Belt et al., 2008; Stein and Macdonald, 2004), and marine pelagic POC is closer to $-24 \%$ (Naidu et al., 2000) but can range from $-17 \%$ to $-30 \%$ (Stein and Macdonald, 2004). Migratory zooplankton may further complicate POC source assignments due to ontogenetic and seasonal migrations that can exceed 1000 vertical meters (Ashjian et al., 2003).

The strength of the biological pump and the delivery of POC to sediments depends on several factors, such as temperature, nutrient availability, sea-ice conditions, timing of sea-ice melt, and zooplankton community dynamics (Honjo et al., 2010). Given that Arctic ecosystems appear uniquely sensitive to changing temperature and sea-ice conditions, there is a clear need to determine the structure and function of the Arctic Ocean carbon cycle. We address this need by reporting the first full suite (dissolved inorganic carbon, DIC; dissolved organic carbon, DOC; and suspended POC, POCsusp) of dual-isotope profiles in the Arctic Ocean at two sites in the deep Canada Basin. These bulk isotope data are valuable as a comparative baseline against which future change can be evaluated, but they also provide evidence that DIC fixation is particularly important in the deep Arctic Ocean.

\section{Methods}

As a part of the 2008 Joint Ocean Ice Study (JOIS), the CCGS Louis S. St Laurent occupied two stations in the Canada Basin of the Arctic Ocean in August 2008 (Fig. 1a). Station CB4 $\left(74^{\circ} 59.998^{\prime} \mathrm{N} ; 150^{\circ} 0.002^{\prime} \mathrm{W} ; 3825 \mathrm{~m}\right)$ is seasonally free of ice, while station CB9 $\left(77^{\circ} 59.859^{\prime} \mathrm{N}\right.$; $150^{\circ} 4.887^{\prime} \mathrm{W} ; 3821 \mathrm{~m}$ ) is semi-permanently ice covered. At each site, water samples were collected at 24 depths using 101 Niskin bottles on a 24-bottle rosette.

DIC samples were collected in combusted $600 \mathrm{ml}$ clear glass DIC bottles, poisoned with $100 \mu \mathrm{HgCl}_{2}$, sealed, and stored in the dark at room temperature to await carbon isotope analysis at the National Ocean Sciences Accelerator Mass Spectrometry (NOSAMS) facility in Woods Hole, Massachusetts (McNichol et al., 1994). The pooled standard deviations for duplicate DIC samples $(n=8)$ were $0.025 \mathrm{mM}$, $0.23 \%$ o $\left(\delta^{13} \mathrm{C}\right)$, and $8.0 \%$ o $\left(\Delta^{14} \mathrm{C}\right)$.

DOC samples were collected in combusted $\left(450{ }^{\circ} \mathrm{C} ; 5 \mathrm{~h}\right)$ amber glass bottles with Teflon-lined caps using ${ }^{14} \mathrm{C}$-clean techniques. One-liter samples were collected at depths greater than $400 \mathrm{~m}$. All other DOC samples were $250 \mathrm{ml}$. Each DOC sample was immediately acidified with $85 \%$ $\mathrm{H}_{3} \mathrm{PO}_{4}(1 \mathrm{ml}$ or $250 \mu \mathrm{l})$ and stored in the dark at $4{ }^{\circ} \mathrm{C}$ until processing at NOSAMS following Beaupre et al. (2007). The DOC samples reported here were not filtered and represent total organic carbon (TOC), although the difference between TOC and DOC was found to be negligible due to extremely low particle concentrations. The pooled standard deviations for duplicate DOC samples $(n=8)$ were $2.2 \mu \mathrm{M}$, $0.28 \% \circ\left(\delta^{13} \mathrm{C}\right)$, and $23 \%$ \% $\left(\Delta^{14} \mathrm{C}\right)$.

POCsusp samples were obtained using submersible McLane ${ }^{\circledR}$ pumps loaded with combusted $142 \mathrm{~mm} \mathrm{GF/F}$ $(0.7 \mu \mathrm{m})$ filters and lowered to specific depths where each one pumped up to 9501 over $150 \mathrm{~min}$. In one instance, a pump deployed to $3805 \mathrm{~m}$ at CB4 failed to start, yet $6.2 \mu \mathrm{mol}$ of OC $\left(\Delta^{14} \mathrm{C}=-247 \%\right.$; $\delta^{13} \mathrm{C}=-25.1 \%$ ) was collected on the filter. This was attributed to DOC that sorbed onto the filter during deployment. Therefore, POCsusp values were corrected for DOC sorption assuming similar sorption onto all sample filters. This DOC sorption "blank" represented 1-19\% of the total OC measured on other sample filters and resulted in an average $\Delta^{14} C_{\text {POCsusp }}$ correction of $+11 \%$ o. Surface POCsusp samples ( $9 \mathrm{~m}$ water depth) were collected through the ship's clean water intake onto combusted $293 \mathrm{~mm}$ GF/F filters. All POC filters were processed and analyzed according to the procedures outlined by Hwang et al. (2009).

Continuous measurements of temperature and conductivity were carried out with a Seabird SBE9 + CTD attached to the rosette. Conductivity was calibrated using discrete salinity samples processed onboard following standard protocols. A temperature-salinity plot of these data (Fig. 1b) facilitates the interpretation of carbon isotope profiles in the context of vertical water mass structure in the Canada Basin. 

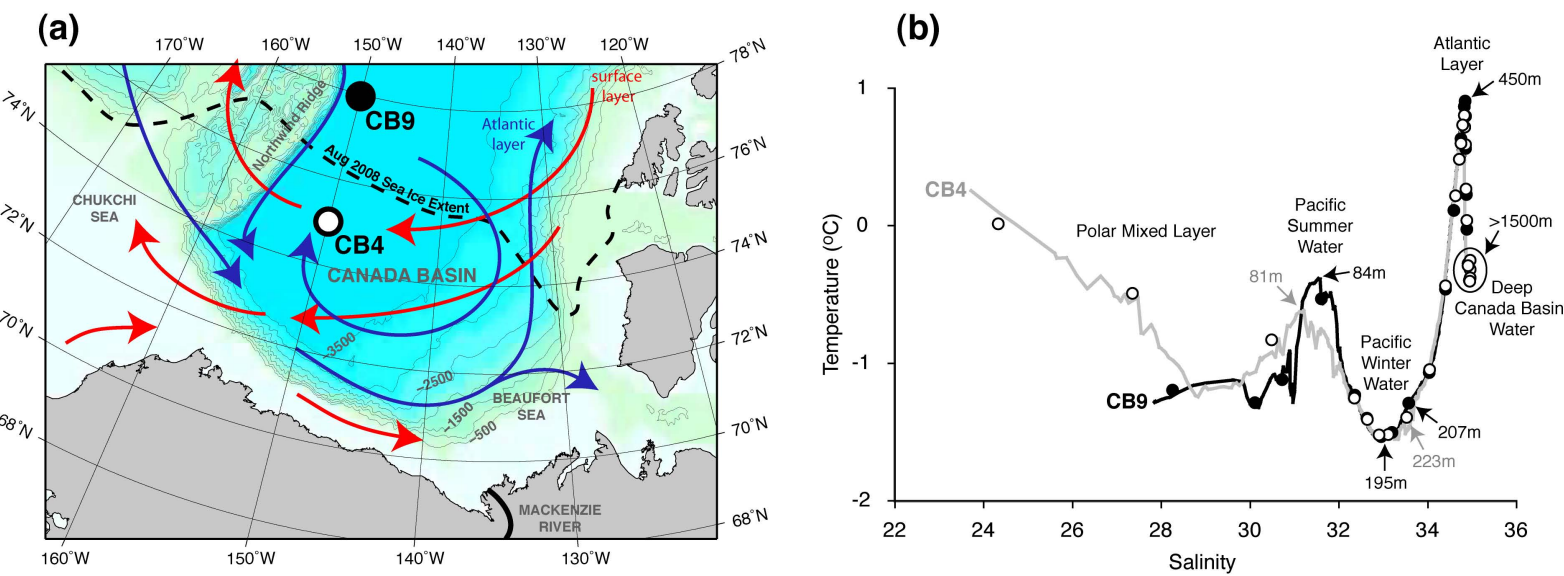

Fig. 1. (a) Sampling stations CB4 and CB9 in the Canada Basin are mapped along with surface (red) and Atlantic (blue) water layer currents (McLaughlin et al., 2009; Stein and Macdonald, 2004) and the approximate sea-ice extent in August 2008 (http://nsidc.org/data/). (b) Water masses in the Canada Basin are characterized by temperature and salinity. Solid lines (grey-CB4; black-CB9) show real-time measurements from sensors attached to the rosette. Discrete points correspond to bottle samples collected for isotopic analyses of DIC and DOC. Displayed depths are used to translate labeled water masses onto depth profiles (Fig. 2).

\section{Results and discussion}

\subsection{Dissolved Inorganic Carbon (DIC)}

In the Canada Basin, $\mathrm{DI}^{14} \mathrm{C}$ generally decreases with depth - from relatively enriched values in the Atlantic layer to uniformly depleted values in the deep basin (Fig. 2). Deep water $\mathrm{DI}^{14} \mathrm{C}$ in the Canada Basin is similar to the deep Makarov Basin but depleted by $\sim 25 \%$ compared to the deep Nansen and Amundsen Basins (Schlosser et al., 1997). And, except for moderate ${ }^{14} \mathrm{C}$ enrichment in the Atlantic layer, the profile of $\mathrm{DI}^{14} \mathrm{C}$ in the Canada Basin has not changed appreciably since 1992 (Jones et al., 1994).

At stations CB4 (seasonally ice-free) and CB9 (semipermanently ice-covered), profiles of DIC, $\mathrm{DI}^{13} \mathrm{C}$, and $\mathrm{DI}^{14} \mathrm{C}$ (Fig. 2) are similar, suggesting that sea-ice coverage is not a major factor controlling the vertical distribution of DIC in the Canada Basin. Instead, DIC profiles largely reflect preformed signals in a highly stratified water column. For example, maximum DIC concentrations are found in Pacific Winter Water (PWW), a layer that accumulates DIC as it flows across the highly productive Chukchi Sea.

\subsection{Dissolved Organic Carbon (DOC)}

DOC profiles (Fig. 2) show that concentration and $\mathrm{DO}^{14} \mathrm{C}$ both decrease with depth following the general pattern seen in other ocean basins (Bauer, 2002; Hansell et al., 2009). Elevated DOC in the Pacific layer may reflect DOC-rich waters from the Beaufort and Chukchi shelves that have subducted with brines during sea-ice formation or been injected into the Canada Basin by mesoscale eddies (Mathis et al., 2007).
A large percentage (31-65\%) of primary production in the Canada Basin is released as DOC (Gosselin et al., 1997), but DOC in the deep Canada Basin remains low $(\sim 40 \mu \mathrm{M})$ due to a weak biological pump, low POC fluxes, and high DOC biodegradation rates (Anderson, 2002). Previous measurements of lignin phenols and ${ }^{13} \mathrm{C}$ isotope signatures pointed to relatively minor contributions from terrestrial $\mathrm{OC}$ to the deep Canada Basin DOC pool (Anderson, 2002; Opsahl et al., 1999).

Yet, the DOC isotope profiles presented here (Fig. 2) and the fact that deep Canada Basin $\mathrm{DO}^{13} \mathrm{C}\left(\delta^{13} \mathrm{C} \sim-23 \%\right.$ o $)$ is more depleted than North Atlantic $\mathrm{DO}^{13} \mathrm{C}\left(\delta^{13} \mathrm{C} \sim-21 \%\right.$; Bauer, 2002) suggests that terrestrial OC has a large influence on deep Canada Basin waters. An obvious source is OC from Arctic rivers $\left(\delta^{13} \mathrm{C} \sim-26\right.$ to $-29 \%$; Goñi et al., 2005; Guo et al., 2007; Naidu et al., 2000; Raymond et al., 2007). While Arctic riverine DOC is largely confined to surface waters, where it is degraded or exported to the North Atlantic Ocean (Benner et al., 2005; Opsahl et al., 1999), riverine POC clearly has the potential to reach the deep Arctic Ocean directly or following deposition in shelf sediments and subsequent resuspension and lateral transport by currents and eddies (Hwang et al., 2008; O'Brien et al., 2011). Moreover, Arctic riverine DOC is unlikely to be a major source of terrestrial OC to the deep Canada Basin because its characteristically enriched ${ }^{14} \mathrm{C}$ values $\left({ }^{14} \mathrm{C} \sim 50 \%\right.$; Raymond et al., 2007) are not consistent with depleted deep Arctic $\mathrm{DO}^{14} \mathrm{C}$ measurements. Arctic riverine POC, on the other hand, is depleted in both ${ }^{13} \mathrm{C}$ and ${ }^{14} \mathrm{C}\left(\delta^{13} \mathrm{C} \sim-27 \%\right.$; $\Delta{ }^{14} \mathrm{C} \sim-600 \%$; Goñi et al., 2005; Guo et al., 2007), and some portion could be converted to DOC on Arctic margins, in shelf sediments, or after transport to the deep basin. On this basis, dual isotope mass balance calculations 


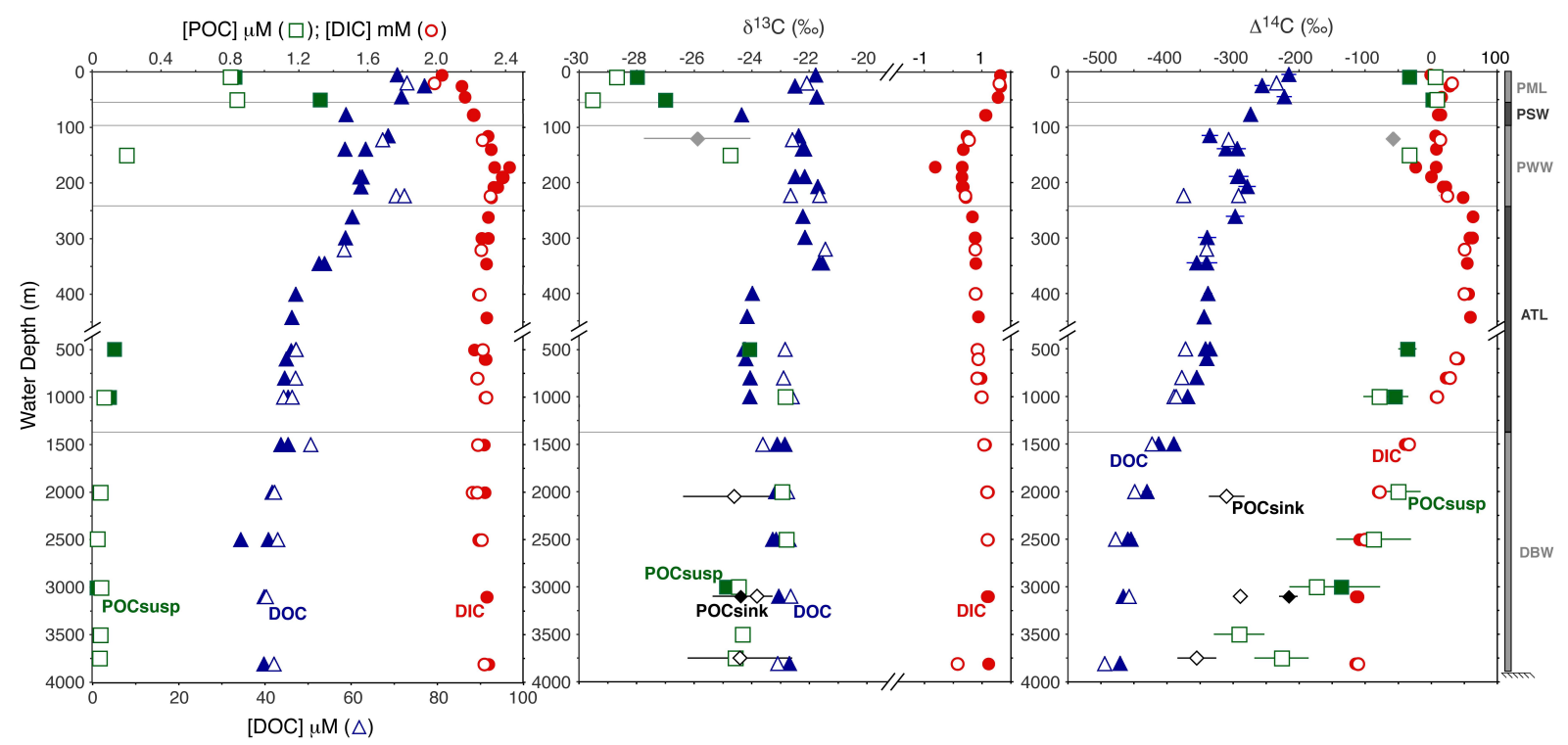

Fig. 2. Full-depth carbon isotope profiles of DOC (blue triangles), POCsusp (green squares), and DIC (red circles) at sites CB4 (open symbols) and CB9 (filled symbols) in the Canada Basin in August 2008. POCsink (black diamonds) represents a flux-weighted average from time-series sediment traps at water depths of $2050 \mathrm{~m}$ (2008-2009), 3100 m (2004-2005; 2007-2009), and 3750 m (2008-2009) (Hwang et al., 2012). POCsink at $120 \mathrm{~m}$ (grey diamonds) is derived from an ice-tethered sediment trap that traversed the Canada Basin and Chukchi Rise in 1997-1998 (Honjo et al., 2010). POCsink error bars show \pm 1 SD for each corresponding time series. Error bars for POCsusp reflect propagated errors $( \pm 1 \mathrm{SD})$ from procedural blank and DOC corrections; DOC errors $( \pm 1 \mathrm{SD})$ reflect propagated errors of blank corrections. Error bars $( \pm 1 \mathrm{SD})$ for DIC reflect analytical uncertainty only. When not visible, error bars are smaller than symbols. Water masses (Polar Mixed Layer - PML; Pacific Summer Water - PSW; Pacific Winter Water - PWW; Atlantic Layer - ATL; and Deep Canada Basin Water - DBW) are delineated according to characteristic temperature and salinity (see Fig. 1b). These data are available in the Supplement in Tables S1-S3.

suggest that $\sim 30 \%$ of deep Canada Basin DOC could be derived from terrestrial POC sources, and aged North Atlantic DOC $\left(\delta^{13} \mathrm{C} \sim-21 \%\right.$; $\Delta{ }^{14} \mathrm{C} \sim-390 \%$; Bauer, 2002) would make up the balance.

$\mathrm{DO}^{13} \mathrm{C}$ profiles at $\mathrm{CB} 4$ and $\mathrm{CB} 9$ share several features. Generally, DOC is more ${ }^{13} \mathrm{C}$-enriched in surface and Pacific layers compared to deeper waters, which points to greater contributions from sea-ice algal production and pre-formed Pacific/Chukchi Sea DOC (Belt et al., 2008; Stein and Macdonald, 2004) or the preferential degradation of ${ }^{13} \mathrm{C}$-depleted DOC (e.g. riverine DOC) in the upper $400 \mathrm{~m}$ at both sites. Likewise, deep waters at each site share similar $\mathrm{DO}^{13} \mathrm{C}$ values $(\sim-23 \%)$. Yet in the core of the Atlantic layer, at depths of $400-1000 \mathrm{~m}, \mathrm{DO}^{13} \mathrm{C}$ values are more depleted at CB9 than at CB4. This offset may reflect greater contributions from terrestrial OC $\left(\delta^{13} \mathrm{C} \sim-26 \%\right.$ o to $-29 \%$; Naidu et al., 2000; Raymond et al., 2007) delivered from the Siberian margin to CB9 by the Atlantic layer boundary current (see Fig. 1a), or DOC derived from microbial consumption of autochthonous POC along the Northwind Ridge $\left(\delta^{13} \mathrm{C} \sim-25 \%\right.$ o to $-27 \%$; Honjo et al., 2010).

Canada Basin $\mathrm{DO}^{14} \mathrm{C}$ values are depleted relative to $\mathrm{DI}^{14} \mathrm{C}$ throughout the water column, and largely reflect the stratification of Atlantic and Pacific source waters in the upper
$1000 \mathrm{~m}$ (Fig. 2). Below $1000 \mathrm{~m}$, the $\mathrm{DO}^{14} \mathrm{C}$ and $\mathrm{DI}^{14} \mathrm{C}$ profiles mirror one another with an offset (380\%o at CB4; $356 \%$ o at CB9) that is similar to other oceans (Druffel and Bauer, 2000).

We also find significant offsets between $\mathrm{DO}^{14} \mathrm{C}$ profiles within the Canada Basin. Below $400 \mathrm{~m}, \mathrm{DO}^{14} \mathrm{C}$ is significantly more enriched (by $\sim 27 \%$ ) at CB9 compared to CB4 (t-test, $p=0.0034)$. This difference points to a weaker biological pump and/or larger contributions from aged and advected $\mathrm{DOC}$ at the interior basin site (CB4). In either case, we might expect to see this $\mathrm{DO}^{14} \mathrm{C}$ offset also reflected in the composition of $\mathrm{PO}^{14} \mathrm{Csusp}$ at both sites due to communication between DOC and POC via heterotrophic respiration of in situ DOC and sorption of DOC onto POCsusp.

\subsection{Suspended Particulate Organic Carbon (POCsusp)}

The Canada Basin is characterized by extremely low POCsusp concentrations (Fig. 2). Those measured in the current study are consistently (and in some cases much) lower than previous reports from nearby locations (Trimble and Baskaran, 2005). This difference can be attributed to the relatively small amount of DOC sorbed onto filters due to the large volumes filtered in this study (see Gardner et al., 
2003) and the fact that our reported POCsusp values have been explicitly corrected for DOC that sorbed onto filters during deployment.

Despite overlapping source isotope signatures, $\mathrm{PO}^{13} \mathrm{Csusp}$ values at mesopelagic $(\sim 200-1000 \mathrm{~m})$ and bathypelagic $(\sim 1000-4000 \mathrm{~m})$ depths in the central Canada Basin $(\sim$ $-23 \%$ to $-24 \%$ ) implicate pelagic plankton sources, whereas surface $\mathrm{PO}^{13} \mathrm{Csusp}$ values $(-27 \%$ o to $-30 \%$ ) point to either river-derived OC or slow-growing phytoplankton (Fig. 2). The relative enrichment of surface $\mathrm{PO}^{13}$ Csusp at CB9 may also reflect proportionately greater contributions from sea ice algae at this ice-covered site.

Radiocarbon data add an additional constraint when interpreting POCsusp profiles. Canada Basin $\mathrm{PO}^{14} \mathrm{C}$ profiles (Fig. 2) support previous evidence from time-series studies of POC collected in sediment traps (POCsink), which suggest that the biological pump in the Arctic is weaker than in other oceans due to a smaller flux of ballast particles (Honjo et al., 2010). $\mathrm{PO}^{14} \mathrm{Csink}$ and $\mathrm{PO}^{14} \mathrm{Csusp}$ in the Canada Basin are both more depleted than at corresponding depths in the Atlantic and Pacific Oceans (Druffel and Williams, 1990; Hwang et al., 2008; McNichol and Aluwihare, 2007), which points to smaller contributions from modern OC to deep waters and sediments of the Canada Basin.

Unlike other oceans, where $\mathrm{PO}^{14} \mathrm{Csink}$ values reflect modern OC from surface ocean primary productivity (Druffel and Williams, 1990; Druffel et al., 1992), in the Canada Basin $\mathrm{PO}^{14}$ Csink is more depleted than $\mathrm{PO}^{14}$ Csusp (Fig. 2) (Hwang et al., 2008, 2012). This discrepancy may be due to the proportionately large influence of ocean margins and shelf-basin particle transport on POCsink in the Arctic or other factors such as bottom currents and the timing of seaice melt, which may affect POCsink and POCsusp differently (Bates et al., 2005; Belicka et al., 2009; Darby et al., 2009; Forest et al., 2007, 2010; Honjo et al., 2010; Hwang et al., 2008). Together, depleted $\mathrm{PO}^{14} \mathrm{C}$ values, high aluminum content, and the timing of sinking particulate fluxes in the Canada Basin (Hwang et al., 2008; O’Brien et al., 2011) suggest that resuspended margin sediments are an important source of pre-aged organic carbon (OC) to the deep Arctic Ocean.

The unique character of Canada Basin $\mathrm{PO}^{14} \mathrm{C}$ profiles has important implications for understanding the sources and fate of POCsusp. In the Canada Basin, $\mathrm{PO}^{14}$ Csusp generally decreases with depth, a feature that has been observed in other oceans and is typically attributed to the sorption of aged DOC (Druffel and Williams, 1990). The fact that $\mathrm{PO}^{14} \mathrm{Csink}$ is more depleted than $\mathrm{PO}^{14}$ Csusp raises the possibility that laterally advected refractory POCsink could be partially responsible for the observed depletion of $\mathrm{PO}^{14}$ Csusp with depth. Benthic nepheloid layers that transport resuspended shelf and slope sediments may also contribute to $\mathrm{PO}^{14} \mathrm{Csusp}$ patterns in the deepest samples (Forest et al., 2007; Hwang et al., 2009).
Many of these explanations rely on some amount of communication between the sinking and suspended pools. In the Canada Basin, POCsink fluxes at $120 \mathrm{~m}$ $\left(10 \mathrm{mmol} \mathrm{C} \mathrm{m}{ }^{-2} \mathrm{yr}^{-1} ; \quad \Delta^{14} \mathrm{C}=-67 \% ; \quad \delta^{13} \mathrm{C}=-25.4 \%\right.$; Honjo et al., 2010) are certainly large enough to affect the character of the POCsusp inventory between 150$3000 \mathrm{~m}\left(73 \mu \mathrm{mol} \mathrm{C} \mathrm{m}{ }^{-3} ; \Delta^{14} \mathrm{C}=-70 \%\right.$; $\delta^{13} \mathrm{C}=-23.8 \%$ o). Nonetheless, it is possible that the difference between the isotopic signatures of $\mathrm{PO}^{14} \mathrm{Csusp}$ and $\mathrm{PO}^{14} \mathrm{Csink}$ is related to mismatched sampling timescales (POCsusp "snapshots" versus POCsink time series). But if this were the case, $\mathrm{PO}^{14}$ Csusp would need to exhibit marked temporal variability since $\mathrm{PO}^{14} \mathrm{Csink}$ was consistently more depleted throughout multi-year deployments (Hwang et al., 2008, 2012).

If we assume that the difference between $\mathrm{PO}^{14} \mathrm{Csusp}$ and $\mathrm{PO}^{14} \mathrm{Csink}$ is not a timescale artifact, then the source of enriched $\mathrm{PO}^{14} \mathrm{Csusp}$ at depth is not immediately clear. One possibility is that these enriched $\mathrm{PO}^{14} \mathrm{Csusp}$ values reflect heterotrophic organisms that consume labile (modern) or semi-labile OC $\left(\Delta^{14} \mathrm{C} \sim-120 \%\right.$; Repeta and Aluwihare, 2006) attached to otherwise refractory POCsink (e.g. White et al., 2007). An alternate explanation is that a significant fraction of POCsusp in the Canada Basin is derived from DIC fixation at depth due to anapleurotic DIC uptake (Rau et al., 1986) or chemoautotrophic organisms such as planktonic Archaea, which are common (if not dominant) below the euphotic zone of the world's oceans (Delong, 2007).

To resolve these questions, isotope mass balance calculations were used to estimate the fraction of POCsusp derived from surface-derived OC (" $f_{\mathrm{SD}}$ "), in situ DIC fixation (" $f_{\mathrm{DF}}$ "), and either advected POC or sorbed DOC (" $f_{\mathrm{A} / \mathrm{s}}$ "):

$$
\begin{aligned}
f_{\mathrm{SD}}+f_{\mathrm{DF}} & +f_{\mathrm{A} / \mathrm{S}}=1 \\
\delta^{13} \mathrm{C}_{\mathrm{POCsusp}} & =f_{\mathrm{SD}}\left(\delta^{13} \mathrm{C}_{\mathrm{SD}}\right)+f_{\mathrm{DF}}\left(\delta^{13} \mathrm{C}_{\mathrm{DF}}\right) \\
& +f_{\mathrm{A} / \mathrm{S}}\left(\delta^{13} \mathrm{C}_{\mathrm{A} / \mathrm{S}}\right) \\
\Delta^{14} \mathrm{C}_{\mathrm{POCsusp}} & =f_{\mathrm{SD}}\left(\Delta^{14} \mathrm{C}_{\mathrm{SD}}\right)+f_{\mathrm{DF}}\left(\Delta^{14} \mathrm{C}_{\mathrm{DF}}\right) \\
& +f_{\mathrm{A} / \mathrm{S}}\left(\Delta^{14} \mathrm{C}_{\mathrm{A} / \mathrm{S}}\right)
\end{aligned}
$$

This system of equations was solved twice for each sample - once assuming no contribution from advected POC, and again assuming no contribution from sorbed DOC. This was necessary in order to account for four carbon sources with only two isotopes. The isotopic values of each end-member were derived from profile data according to Table 1 and are specific to both location and water depth. Relatively large uncertainties in POCsusp were taken into account by solving the mass balance for the full range ( \pm 1 standard deviation) of POCsusp isotope values.

Mass balance results (Table 2) indicate that $\mathrm{PO}^{14}$ Csusp in the Canada Basin requires large contributions (41-71\%) from surface-derived OC, with smaller but significant (4$22 \%$ ) contributions from in situ DIC fixation, particularly at 
Table 1. Determining end-member isotope values for POCsusp mass balance calculations.

\begin{tabular}{|c|c|c|c|c|}
\hline & $\begin{array}{l}\text { Surface-Derived OC } \\
\left(\delta^{13} \mathrm{C}_{\mathrm{SD}} ; \Delta^{14} \mathrm{C}_{\mathrm{SD}}\right)\end{array}$ & $\begin{array}{c}\text { DIC Fixation } \\
\left(\delta^{13} \mathrm{C}_{\mathrm{DF}} ; \Delta^{14} \mathrm{C}_{\mathrm{DF}}\right)\end{array}$ & $\begin{array}{c}\text { Advected POC } \\
\left(\delta^{13} \mathrm{C}_{\mathrm{A}} ; \Delta^{14} \mathrm{C}_{\mathrm{A}}\right)\end{array}$ & $\begin{array}{c}\text { Sorbed DOC } \\
\left(\delta^{13} \mathrm{C}_{\mathrm{S}} ; \Delta^{14} \mathrm{C}_{\mathrm{S}}\right)\end{array}$ \\
\hline $\begin{array}{l}\text { Isotope values } \\
\text { derived from: }\end{array}$ & POCsusp at $50 \mathrm{~m}$ & in situ DIC & $\begin{array}{l}\Delta^{14} \mathrm{C}=-260 \% \\
\delta^{13} \mathrm{C}=-24.5 \%\end{array}$ & in situ DOC \\
\hline Note(s): & $\begin{array}{l}\text { Chlorophyll } \\
\text { maxima at } \\
64 \mathrm{~m}(\mathrm{CB} 4) \text { and } \\
45 \mathrm{~m}(\mathrm{CB} 9) \text {. }\end{array}$ & $\begin{array}{l}\text { Assumes fixation } \\
\text { by the } 3 \mathrm{HP} / 4 \mathrm{HB} \\
\text { pathway and a } \\
{ }^{13} \mathrm{C} \text { fractionation } \\
\text { factor of } 4 \pm 4 \% \text { o. }\end{array}$ & $\begin{array}{l}\text { Extrapolating } \\
\text { POCsink } \\
\text { isotopes and } \\
\% \mathrm{Al} \text { at CB4 } \\
\text { back to crustal } \\
\text { Al content. }\end{array}$ & $\begin{array}{l}\text { Sorbed onto } \\
\text { POCsusp or } \\
\text { incorporated } \\
\text { into bacterial } \\
\text { biomass. }\end{array}$ \\
\hline Reference(s): & This study & $\begin{array}{l}\text { This study; } \\
\text { (Pearson, 2010) }\end{array}$ & $\begin{array}{l}\text { This study; } \\
\text { (Hwang et al., } \\
\text { 2010, 2008) }\end{array}$ & This study \\
\hline
\end{tabular}

Table 2. Contributions to POCsusp in the Canada Basin based on isotope mass balance calculations.

\begin{tabular}{llll}
\hline & $\begin{array}{c}\text { Surface-Derived } \\
\text { OC }(\%)\end{array}$ & \multicolumn{1}{c}{$\begin{array}{c}\text { DIC Fixation } \\
(\%)\end{array}$} & $\begin{array}{c}\text { Advected POC/ } \\
\text { Sorbed DOC } \\
(\%)\end{array}$ \\
\hline CB4 150m & $71(66-74)$ & $15(14-16)$ & $14(10-19)$ \\
CB4 1000 m & $53(41-63)$ & $20(18-22)$ & $27(16-41)$ \\
CB9 1000 m & $70(61-78)$ & $10(9-11)$ & $20(12-31)$ \\
CB4 2000 m & $67(53-75)$ & $22(19-27)$ & $12(1-28)$ \\
CB4 3000 m & $41(15-61)$ & $8(4-12)$ & $51(27-81)$ \\
CB9 3000 m & $56(24-78)$ & $4(1-6)$ & $41(16-75)$ \\
\hline
\end{tabular}

Numbers in parentheses show the extreme range of solutions to the mass balance given full uncertainties in $\mathrm{PO}^{14}$ Csusp and the DIC fixation fractionation factor, as well as separate treatment of advected POC and sorbed DOC calculations.

intermediate depths (e.g. $2000 \mathrm{~m}$ ) and at the interior basin site (CB4). The balance in these calculations (12-51\%) is attributed to either in situ DOC or advected/refractory POC. These calculations provide quantitative support that the POCsusp pool in the meso- and bathypelagic Arctic contains carbon derived from both in situ DIC and surface-derived $\mathrm{OC}$, and that the relative proportion of each source varies with depth and location (Table 2). These results also lend bulk isotopic evidence to support microbiological studies that have recently found evidence for the dominance of chemoautotrophic communities in deep waters of the Arctic, Atlantic, and Pacific (Hansman et al., 2009; Herndl et al., 2005; Ingalls et al., 2006; Kirchman et al., 2007; Wuchter et al., 2006).

The source of chemical energy driving deep Arctic DIC fixation remains uncertain. One possibility is that chemoautotrophy is driven by nitrifying organisms that utilize $\mathrm{NH}_{4}^{+}$ from the decomposition of suspended and sinking particulate organic matter (Karl et al., 1984). If we assume that the average vertical organic nitrogen flux between 150-3000 m
(2.8 $\mathrm{mmol} \mathrm{N} \mathrm{m}^{-2} \mathrm{yr}^{-1}$; Honjo et al., 2010) is entirely converted to $\mathrm{NH}_{4}^{+}$and nitrifiers require approximately $10 \mathrm{NH}_{4}^{+}$ molecules to fix a single molecule of $\mathrm{CO}_{2}$ (e.g. Wuchter et al., 2006), then sinking organic nitrogen fluxes alone could support DIC fixation rates as high as $280 \mu \mathrm{mol} \mathrm{C} \mathrm{m}^{-2} \mathrm{yr}^{-1}$, which is relatively large compared to our isotope-based estimates of the fraction of POCsusp derived from in situ DIC fixation at these depths $\left(3-16 \mu \mathrm{mol} \mathrm{C} \mathrm{m}^{-3}\right)$. And while further mechanistic, genetic, and compound-specific isotope studies are clearly needed, our results provide bulk isotopic evidence that DIC fixation contributes significantly to POCsusp in the meso- and bathypelagic Arctic.

\section{Conclusions}

Taken together, these findings have intriguing implications for our understanding of the Arctic Ocean carbon cycle; in particular the weakness of the biological pump, the extent of terrestrial OC contributions, the interplay between the dissolved and particulate OC pools, and the importance of DIC fixation at depth. This study also sets a valuable baseline from which to identify future changes in the Arctic Ocean.

\section{Supplementary material related to this article is available online at: http://www.biogeosciences.net/9/1217/2012/ bg-9-1217-2012-supplement.pdf.}

Acknowledgements. We thank William Burt, Mike Dempsey, Jim Dunn, Roger François, Jeomshik Hwang, Richard Krishfield, Steven Manganini, Daniel Montluçon, Will Ostrom, Michiyo Yamamoto-Kawai, and Sarah Zimmermann, as well as the staff of the NOSAMS facility at Woods Hole Oceanographic Institution (WHOI), and the captain and crew of the CCGS Louis S. St Laurent. The WHOI Arctic Research Initiative funded 
radiocarbon analyses. The 2008 JOIS hydrographic program was supported by Fisheries and Oceans Canada, the Canadian International Polar Year Office, and the US National Science Foundation (OPP-0424864; lead-PI Andrey Proshutinsky).

Edited by: G. Herndl

\section{References}

Anderson, L. G.: DOC in the Arctic Ocean, in: Biogeochemistry of Marine Dissolved Organic Matter, edited by: Hansell, D. and Carlson, C. A., Academic Press, Amsterdam, 774 pp., 2002.

Ashjian, C. J., Campbell, R. G., Welch, H. E., Butler, M., and Van Keuren, D.: Annual cycle in abundance, distribution, and size in relation to hydrography of important copepod species in the western Arctic Ocean, Deep-Sea Res. Pt. I, 50, 1235-1261, 2003.

Bates, N. R., Hansell, D. A., Moran, S. B., and Codispoti, L. A.: Seasonal and spatial distribution of particulate organic matter (POM) in the Chukchi and Beaufort Seas, Deep-Sea Res. Pt. II, 52, 3324-3343, 2005.

Bauer, J. E.: Carbon isotopic composition of DOM, in: Biogeochemistry of Marine Dissolved Organic Matter, edited by: Hansell, D. and Carlson, C. A., Academic Press, Amsterdam, 774 pp., 2002.

Beaupre, S. R., Druffel, E. R. M., and Griffin, S.: A low-blank photochemical extraction system for concentration and isotopic analyses of marine dissolved organic carbon, Limnol. Oceanogr.Meth., 5, 174-184, 2007.

Belicka, L. L., Macdonald, R. W., and Harvey, H. R.: Sources and transport of organic carbon to shelf, slope, and basin surface sediments of the Arctic Ocean, Deep-Sea Res. Pt. I, 49, 1463-1483, 2002.

Belicka, L. L., Macdonald, R. W., and Harvey, H. R.: Trace element and molecular markers of organic carbon dynamics along a shelfbasin continuum in sediments of the western Arctic Ocean, Mar. Chem., 115, 72-85, 2009.

Belt, S. T., Masse, G., Vare, L. L., Rowland, S. J., Poulin, M., Sicre, M. A., Sampei, M., and Fortier, L.: Distinctive C-13 isotopic signature distinguishes a novel sea ice biomarker in Arctic sediments and sediment traps, Mar. Chem., 112, 158-167, 2008.

Benner, R., Louchouarn, P., and Amon, R. M. W.: Terrigenous dissolved organic matter in the Arctic Ocean and its transport to surface and deep waters of the North Atlantic, Global Biogeochem. Cy., 19, GB2025, doi:10.1029/2004GB002398, 2005.

Darby, D. A., Ortiz, J., Polyak, L., Lund, S., Jakobsson, M., and Woodgate, R. A.: The role of currents and sea ice in both slowly deposited central Arctic and rapidly deposited Chukchi-Alaskan margin sediments, Global Planet. Change, 68, 56-70, 2009.

Delong, E. F.: Microbial Domains in the Ocean: A Lesson from the Archaea, Oceanography, 20, 124-129, 2007.

Druffel, E. R. M. and Bauer, J. E.: Radiocarbon distributions in Southern Ocean dissolved and particulate organic matter, Geophys. Res. Lett., 27, 1495-1498, 2000.

Druffel, E. R. M. and Williams, P. M.: Identification of a Deep Marine Source of Particulate Organic-Carbon Using Bomb C-14, Nature, 347, 172-174, 1990.

Druffel, E. R. M., Williams, P. M., Bauer, J. E., and Ertel, J. R.: Cycling of dissolved and particulate organic matter in the open ocean, J. Geophys. Res., 97, 15639-15659, 1992.
Forest, A., Sampei, M., Hattori, H., Makabe, R., Sasaki, H., Fukuchi, M., Wassmann, P., and Fortier, L.: Particulate organic carbon fluxes on the slope of the Mackenzie Shelf (Beaufort Sea): Physical and biological forcing of shelf-basin exchanges, J. Marine Syst., 68, 39-54, 2007.

Forest, A., Belanger, S., Sampei, M., Sasaki, H., Lalande, C., and Fortier, L.: Three-year assessment of particulate organic carbon fluxes in Amundsen Gulf (Beaufort Sea): Satellite observations and sediment trap measurements, Deep-Sea Res. Pt. I, 57, 125$142,2010$.

Gardner, W. D., Richardson, M. J., Carlson, C. A., Hansell, D., and Mishonov, A. V.: Determining true particulate organic carbon: bottles, pumps and methodologies, Deep-Sea Res. Pt. II, 50, 655-674, 2003.

Goericke, R. and Fry, B.: Variations of marine plankton delta C13 with latitude, temperature, and dissolved $\mathrm{CO}_{2}$ in the world ocean, Global Biogeochem. Cy., 8, 85-90, 1994.

Goñi, M. A., Yunker, M. B., Macdonald, R. W., and Eglinton, T. I.: The supply and preservation of ancient and modem components of organic carbon in the Canadian Beaufort Shelf of the Arctic Ocean, Mar. Chem., 93, 53-73, 2005.

Gosselin, M., Levasseur, M., Wheeler, P. A., Horner, R. A., and Booth, B. C.: New measurements of phytoplankton and ice algal production in the Arctic Ocean, Deep-Sea Res. Pt. II, 44, 16231644, 1997.

Guay, C. K. H., McLaughlin, F. A., and Yamamoto-Kawai, M.: Differentiating fluvial components of upper Canada Basin waters on the basis of measurements of dissolved barium combined with other physical and chemical tracers, J. Geophys. Res., 114, C00A09, doi:10.1029/2008JC005099, 2009.

Guo, L. D., Ping, C. L., and Macdonald, R. W.: Mobilization pathways of organic carbon from permafrost to arctic rivers in a changing climate, Geophys. Res. Lett., 34, L13603, doi:10.1029/2007GL030689, 2007.

Hansell, D. A., Carlson, C. A., Repeta, D. J., and Schlitzer, R.: Dissolved organic matter in the ocean - a controversy stimulates new insights, Oceanography, 22, 202-211, 2009.

Hansman, R. L., Griffin, S., Watson, J. T., Druffel, E. R. M., Ingalls, A. E., Pearson, A., and Aluwihare, L. I.: The radiocarbon signature of microorganisms in the mesopelagic ocean, P. Natl. Acad. Sci., 106, 6513-6518, 2009.

Herndl, G. J., Reinthaler, T., Teira, E., van Aken, H., Veth, C., Pernthaler, A., and Pernthaler, J.: Contribution of Archaea to total prokaryotic production in the deep Atlantic Ocean, Appl. Environ. Microb., 71, 2303-2309, 2005.

Honjo, S., Krishfield, R. A., Eglinton, T. I., Manganini, S. J., Kemp, J. N., Doherty, K., Hwang, J., McKee, T. K., and Takizawa, T.: Biological pump processes in the cryopelagic and hemipelagic Arctic Ocean: Canada Basin and Chukchi Rise, Prog. Oceanogr., 85, 137-170, 2010.

Hwang, J., Eglinton, T. I., Krishfield, R. A., Manganini, S. J., and Honjo, S.: Lateral organic carbon supply to the deep Canada Basin, Geophys. Res. Lett., 35, L11607, doi:10.1029/2008GL034271, 2008.

Hwang, J., Montluçon, D., and Eglinton, T. I.: Molecular and isotopic constraints on the sources of suspended particulate organic carbon on the northwestern Atlantic margin, Deep-Sea Res. Pt. I, 56, 1284-1297, 2009.

Hwang, J., Druffel, E. R. M., and Eglinton, T. I.: Widespread 
influence of resuspended sediments on oceanic particulate organic carbon: Insights from radiocarbon and aluminum contents in sinking particles, Global Biogeochem. Cy., 24, GB4016, doi:10.1029/2010GB003802, 2010.

Hwang, J., Manganini, S. J., Krishfield, R. A., Griffith, D. R., Honjo, S., McLaughlin, F. A., Macdonald, R. W., and Eglinton, T. I.: Temporal and spatial variability of particle transport in the deep Canada Basin, in preparation, 2012.

Ingalls, A. E., Shah, S. R., Hansman, R. L., Aluwihare, L. I., Santos, G. M., Druffel, E. R. M., and Pearson, A.: Quantifying archaeal community autotrophy in the mesopelagic ocean using natural radiocarbon, P. Natl. Acad. Sci., 103, 6442-6447, 2006.

Jones, G. A., Gagnon, A. R., von Reden, K. F., McNichol, A. P., and Schneider, R. J.: High-precision AMS radiocarbon measurements of central Arctic Ocean sea waters, Nucl. Instrum. Meth. B, 92, 426-430, 1994.

Karl, D. M., Knauer, G. A., Martin, J. H., and Ward, B. B.: Bacterial chemolithotrophy in the ocean is associated with sinking particles, Nature, 309, 54-56, 1984.

Kennedy, H., Thomas, D. N., Kattner, G., Haas, C., and Dieckmann, G. S.: Particulate organic matter in Antarctic summer sea ice: concentration and stable isotopic composition, Mar. Ecol.-Prog. Ser., 238, 1-13, 2002.

Kirchman, D. L., Elifantz, H., Dittel, A. I., Malmstrom, R. R., and Cottrell, M. T.: Standing stocks and activity of Archaea and Bacteria in the western Arctic Ocean, Limnol. Oceanogr., 52, 495507, 2007.

Mathis, J. T., Pickart, R. S., Hansell, D. A., Kadko, D., and Bates, N. R.: Eddy transport of organic carbon and nutrients from the Chukchi Shelf: Impact on the upper halocline of the western Arctic Ocean, J. Geophys. Res., 112, C05011, doi:10.1029/2006JC003899, 2007.

McGuire, A. D., Anderson, L. G., Christensen, T. R., Dallimore, S., Guo, L. D., Hayes, D. J., Heimann, M., Lorenson, T. D., Macdonald, R. W., and Roulet, N.: Sensitivity of the carbon cycle in the Arctic to climate change, Ecol. Monogr., 79, 523-555, 2009.

McLaughlin, F. A., Carmack, E. C., Williams, W. J., Zimmermann, S., Shimada, K., and Itoh, M.: Joint effects of boundary currents and thermohaline intrusions on the warming of Atlantic water in the Canada Basin, 1993-2007, J. Geophys. Res., 114, C00A12, doi:10.1029/2008JC005001, 2009.

McNichol, A. P. and Aluwihare, L. I.: The power of radiocarbon in biogeochemical studies of the marine carbon cycle: Insights from studies of dissolved and particulate organic carbon (DOC and POC), Chem. Rev., 107, 443-466, 2007.

McNichol, A. P., Osborne, E. A., Gagnon, A. R., Fry, B., and Jones, G. A.: TIC, TOC, DIC, DOC, PIC, POC - Unique Aspects in the Preparation of Oceanographic Samples for C-14 Ams. Nucl. Instrum. Meth. B, 92, 162-165, 1994.

Naidu, A. S., Cooper, L. W., Finney, B. P., Macdonald, R. W., Alexander, C., and Semiletov, I. P.: Organic carbon isotope ratios (delta C-13) of Arctic Amerasian Continental shelf sediments, Int. J. Earth Sci., 89, 522-532, 2000.

O'Brien, M. C., Melling, H., Pedersen, T. F., and Macdonald, R. W.: The role of eddies and energetic ocean phenomena in the transport of sediment from shelf to basin in the Arctic, J. Geophys. Res., 116, C08001, doi:10.1029/2010JC006890, 2011.

Opsahl, S., Benner, R., and Amon, R. M. W.: Major flux of terrigenous dissolved organic matter through the Arctic Ocean, Limnol.
Oceanogr., 44, 2017-2023, 1999.

Pearson, A.: Pathways of carbon assimilation and their impact on organic matter d13C values, in: Handbook of Hydrocarbon and Lipid Microbiology, edited by: Timmis, K. N., Springer-Verlag, Berlin, 2010.

Rau, G. H., Karl, D. M., and Carney, R. S.: Does inorganic carbon assimilation cause C-14 depletion in deep-sea organisms, DeepSea Res., 33, 349-357, 1986.

Raymond, P. A., McClelland, J. W., Holmes, R. M., Zhulidov, A. V., Mull, K., Peterson, B. J., Striegl, R. G., Aiken, G. R., and Gurtovaya, T. Y.: Flux and age of dissolved organic carbon exported to the Arctic Ocean: A carbon isotopic study of the five largest arctic rivers, Global Biogeochem. Cy., 21, GB4011, doi:10.1029/2007GB002934, 2007.

Repeta, D. J. and Aluwihare, L. I.: Radiocarbon analysis of neutral sugars in high-molecular-weight dissolved organic carbon: Implications for organic carbon cycling, Limnol. Oceanogr., 51, 1045-1053, 2006.

Schlosser, P., Kromer, B., Ekwurzel, B., Bonisch, G., McNichol, A., Schneider, R., vonReden, K., Ostlund, H. G., and Swift, J. H.: The first trans-Arctic C-14 section: Comparison of the mean ages of the deep waters in the Eurasian and Canadian basins of the Arctic Ocean, Nucl. Instrum. Meth. B, 123, 431-437, 1997.

Serreze, M. C., Walsh, J. E., Chapin, F. S., Osterkamp, T., Dyurgerov, M., Romanovsky, V., Oechel, W. C., Morison, J., Zhang, T., and Barry, R. G.: Observational evidence of recent change in the northern high-latitude environment, Climatic Change, 46, 159-207, 2000.

Shimada, K., Itoh, M., Nishino, S., McLaughlin, F., Carmack, E., and Proshutinsky, A.: Halocline structure in the Canada basin of the arctic ocean, Geophys. Res. Lett., 32, L03605, doi:10.1029/2004GL021358, 2005.

Stein, R. and Macdonald, R. W.: The Organic Carbon Cycle in the Arctic Ocean, Springer, Berlin, 2004.

Trimble, S. M. and Baskaran, M.: The role of suspended particulate matter in Th-234 scavenging and Th-234-derived export fluxes of POC in the Canada Basin of the Arctic Ocean, Mar. Chem., 96, 1-19, 2005.

White, H. K., Reddy, C. M., and Eglinton, T. I.: Relationships between carbon isotopic composition and mode of binding of natural organic matter in selected marine sediments, Org. Geochem., 38, 1824-1837, 2007.

Wuchter, C., Abbas, B., Coolen, M. J. L., Herfort, L., van Bleijswijk, J., Timmers, P., Strous, M., Teira, E., Herndl, G. J., Middelburg, J. J., Schouten, S., and Damste, J. S. S.: Archaeal nitrification in the ocean, P. Natl. Acad. Sci., 103, 12317-12322, 2006.

Yamamoto-Kawai, M., McLaughlin, F. A., Carmack, E. C., Nishino, S., and Shimada, K.: Freshwater budget of the Canada Basin, Arctic Ocean, from salinity, delta O-18, and nutrients, J. Geophys. Res., 113, C01007, doi:10.1029/2006JC003858, 2008.

Yamamoto-Kawai, M., McLaughlin, F. A., Carmack, E. C., Nishino, S., Shimada, K., and Kurita, N.: Surface freshening of the Canada Basin, 2003-2007: River runoff versus sea ice meltwater, J. Geophys. Res., 114, C00A05, doi:10.1029/2008JC005000, 2009. 